\title{
MENGATASI MASALAH HUBUNGAN SOSIAL MAHASISWA MELALUI KONSELING TEMAN SEBAYA
}

\author{
Selvia Nelis \\ Sekolah Tinggi Agama Islam (STAI) Yasni Muara Bungo \\ e-mail: selvianelis09@gmail.com
}

\begin{abstract}
The main problem of this research is how to overcome the problem of social relations through peer counseling, including dissociative social relations. The type of research used is an experiment which aims to compare the experimental group with the control group. Student population. data collection using questionnaires and processed using statistical formulas ( $t$ test). Based on the results of the study found a difference in social relations scores between the experimental group and the control group, namely in the experimental group there was an increase while in the control group there was a decrease. after $t$ test, there is a difference between t count (to) and $\mathrm{t}$ table (tt), at a significant level of $1 \%$. This means that peer counseling can overcome the problem of student social relations significantly. that is, $t$ count is greater than t table. (3) there is a change after being given peer counseling services to the experimental group, the problem of student social relations can be alleviated. This means that the research objectives are achieved.
\end{abstract}

Keywords: social relations, counseling, peers.

\begin{abstract}
ABSTRAK
Masalah pokok penelitian ini adalah bagaimana mengatasi masalah hubungan sosial melalui konseling teman sebaya, meliputi hubungan sosial disosiatif. Jenis penelitian yang digunakan adalah eksperimen yang bertujuan untuk membandingkan kelompok eksperimen dengan kelompok kontrol. Populasiny mahasiswa. pengumpulan data menggunakan angket dan diolah menggunakan rumus statistik (Uji t). Berdasarkan hasil penelitian ditemukan adanya perbedaan skor hubungan sosial antara kelompok eksperimen dengan kelompok kontrol, yaitu pada kelompok eksperimen terjadi peningkatan sedangkan pada kelompok kontrol terjadi penurunan. setelah Uji t, terdapatnya perbedaan antara $t$ hitung $\left(\mathrm{t}_{\mathrm{o}}\right)$ dengan $\mathrm{t}$ tabel $\left(\mathrm{t}_{\mathrm{t}}\right)$, pada taraf signifikan 1\%. Artinya konseling teman sebaya dapat mengatasi masalah hubungan sosial mahasiswa dengan signifikan. yaitu thitung lebih besar dibandingkan dengan $t_{\text {tabell }}$. (3) terdapat perubahan setelah diberikan layanan konseling teman sebaya pada kelompok ekperimen, masalah hubungan sosial mahasiswa dapat terentaskan. Artinya tercapai tujuan penelitian.
\end{abstract}

Kata Kunci: hubungan sosial, konseling, teman sebaya.

Nur El-Islam, Volume 5, Nomor 2, Oktober 2018 


\section{A. PENDAHULUAN}

\section{Latar Belakang}

Mahasiswa merupakan manusia yang tumbuh dan berkembang di dalam lingkungannya, baik lingkungan fisik maupun lingkungan sosial. Lingkungan sosial dapat memberi banyak pengaruh terhadap pembentukan berbagai aspek kehidupan terutama psikis. Sunarto menyatakan bahwa "manusia itu adalah makhluk sosial, senantiasa berhubungan dengan sesama manusia. Bersosialisasi pada dasarnya merupakan proses penyesuaian diri terhadap lingkungan kehidupan sosial, bagaimana seharusnya hidup dalam kelompok kecil maupun masyarakat kecil". ${ }^{1}$

Berdasarkan kutipan di atas dapat dipahami bahwa manusia itu saling membutuhkan antara satu sama lain. Manusia membutuhkan orang lain dan saling mempengaruhi, membantu dalam pemenuhan kebutuhannya karena itu manusia adalah makhluk sosial yang tidak dapat hidup tanpa orang lain. Tiada seorangpun yang menemukan kehidupan yang menyenangkan dan membahagiakan apabila orang lain tidak pernah berperan terhadapnya.

Kehidupan sehari-hari setiap orang menampilkan kebersamaannya dengan orang lain, sehingga bertolak dari hal tersebut maka dalam kehidupan dibutuhkan sekali hubungan sosial. Piort Sztompka mengemukakan bahwa hubungan sosial adalah "sesuatu yang menghubungkan individu". ${ }^{2}$ Masing-masing individu mempunyai gagasan, pemikiran, dan keyakinan yang mungkin serupa atau berlainan serta mempunyai aturan yang mungkin membimbing perilaku mereka yang mungkin mereka saling mendukung atau saling bertentangan.

Senada dengan itu, Muhammad Ali mengemukakan bahwa“ hubungan sosial adalah cara individu bereaksi terhadap orang-orang disekitarnya dan bagaimana pengaruh hubungan itu terhadap

\footnotetext{
${ }^{1}$ Sunarto, Perkembangan Peserta Dididk, (Jakarta: PT Rineka Cipta, 1999), cet-1, h. 126.

${ }^{2}$ Piort Sztompka, Sosiologi Perubahan Sosial, (Jakarta: Prenada Media, 2004), h.11.
} 
dirinya". ${ }^{3}$ Berdasarkan kutipan di atas dapat dipahami bahwa hubungan sosial merupakan hubungan timbal balik yang terjadi antara individu dengan orang lain dan individu dengan lingkungannya sehingga memberi pengaruh timbal balik kepada individu dan orang tersebut. Secara hakiki setiap individu akan selalu hidup bersama dan saling berinteraksi dalam kehidupannya. Dengan demikian setiap kegiatan akan diiringi dengan adanya hubungan baik itu secara sengaja.

Pentingnya memberikan pendidikan dan pengetahuan mengenai bagaimana berinteraksi dengan lawan jenis secara baik dan sehat. Makanya dalam proses pendidikan yang di dalamnya terdapat layanan konseling untuk mengatasi masalah hubungan sosial perlu menjadi perhatian khusus dalam bimbingan konseling. Hal ini menjadi bagian dari pengembangan yaitu bidang pengembangan bidang sosial dan keberagamaan ini dapat direalisasikan melalui berbagai layanan konseling yang dilakukan secara efektif dan efisien sehingga tujuan yang diharapkan dapat tercapai.

Konseling merupakan proses pemberian layanan bantuan kepada seseorang atau sekelompok orang dengan sungguh-sungguh dalam upaya mengentaskan permasalahan yang dialaminya dan mengembangkan potensi yang dimilikinya serta mampu menyesuiakan diri dengan lingkungan. Seiring dengan itu Sofyan S. Willis menjelaskan bahwa:

Konseling adalah upaya yang dilakukan seorang pembimbing yang terlatih dan berpengalaman terhadap individu-individu yang membutuhkannya, agar individu tersebut berkembang potensinya secara optimal, maupun mengatasi masalahnya dan mampu menyesuaikan diri terhadap lingkungan yang selalu berubah. ${ }^{4}$

\footnotetext{
${ }^{3}$ Muhammad Ali dkk, Psikologi Remaja Perkembangan Peserta Didik (Jakarta: Bumi Aksara, 2004), h. 85.

${ }^{4}$ Sofyan S. Willis, Konseling Individual Teori dan Praktek (Bandung: Alfabeta, 2004), h. 18.
} 


\section{Identifikasi Masalah}

Berdasarkan permasalahan di atas, maka adapun yang menjadi identifikasi masalah adalah:

a. Masalah hubungan sosial ditinjau dari faktor yang melatarbelakanginya.

b. Mengatasi masalah hubungan sosial mahasiswa melalui konseling teman sebaya.

c. Rumusan program konseling berdasarkan masalah hubungan sosial mahasiswa.

d. Pengaruh hubungan sosial terhadap hasil belajar mahasiswa.

e. Hubungan sosial ditinjau dari pencapaian tugas perkembangan Mahasiswa dan rumusan program pengembangannya.

\section{Kajian Teori}

a. Pengertian Hubungan Sosial

Hubungan sosial individu berkembang karena adanya dorongan rasa ingin tahu dan memiliki terhadap sesuatu yang ada di sekitarnya. Dalam perkembangannya setiap individu ingin tahu bagaimana cara melakukan hubungan secara baik, aman dengan lingkungan sekitarnya. Baik yang bersifat fisik maupun sosial. Hubungan sosial itu terjadi sejak kecil. Enung Fatimah megemukakan bahwa:

"Kebutuhan bergaul dan berhubungan sosial dengan orang lain ini mulai dirasakan sejak anak berumur enam bulan. Pada usia itu anak sudah mampu mengenal manusia lain, terutama ibu, ayah, dan anggota keluarga lain. Anak sudah mampu membedakan perilaku sosial, seperti marah, senyum, dan kasih sayang, dan akhirnya dia menyadari bahwa manusia itu saling membutuhkan satu sama lain dalam memenuhi dan mempertahankan kehidupan di masyarakat". ${ }^{5}$

${ }^{5}$ Enung Fatimah, Psikologi Perkembangan (Perkembangan Peserta Didik) (Bandung: Pustaka Setia, 2006), h. 89. 
Selanjutnya Soerjono Soekanto menjelaskan bahwa hubungan sosial merupakan:

"Masing-masing pihak terhadap pihak yang dihubunginya. Isinya mungkin mencakup konflik, sikap bermusuhan, daya tarik seksual, persahabatan, kepercayaan, dan lain sebagainya. Di lain pihak, isinya mungkin adalah menyangkut pemenuhan suatu kebutuhan, pengelakan terhadap kewajiban, ketegasan agar mentaati perjanjian dan seterusnya". ${ }^{6}$

\section{b. Tahap-Tahap Pembentukan Hubungan Sosial}

\section{1). Pembentukan hubungan}

Tahap ini sering disebut dengan tahap pengenalan. Steve Duck (Jalaluddin Rakhmat) mengemukakan bahwa: Acquaintance is a communication process whereby an individual transmits (consciously) or conveys (somerimes unitentionally) information about his personality structure and content to potential friends, using subtly different means at different tsages of the friendship's development, Artinya perkenalan adalah proses komunikasi dimana individu mengirimkan (secara sadar) atau menyampaikan (kadang-kadang tidak disengaja) informasi tentang struktur dan isi dari kepribadiannya kepada bakal sahabatnya, dengan menggunakan cara-cara yang agak berbeda pada bermacammacam tahap perkembangan persahabatan. ${ }^{7}$

2). Peneguhan hubungan

a) Keakraban merupakan pemenuhan kebutuhan akan kasih sayang, hubunagn interpersonal akan terpilihara apabila kedua belah pihak sepakat tentang keakraban yang diperlukan.

b) Kesepakatan, merupakan kesepakatan tentang siapa yang akan mengontrol siapa, dan bila mana jika dua orang mempunyai pendapat yang berbeda sebelum mengambil keputusan, siapakah yang harus berbicara lebih banyak, siapa yang menentukan, siapakah yang lebih dominan, konflik terjadi umumnya bila

\footnotetext{
${ }^{6}$ Soerjono Soekanto, Mengenal Tujuh Tokoh Sosiologi (Jakarta: PT RajaGrafindo Persada, 2011), h. 45.

${ }^{7}$ Ibid, h. 125.
} 
masing-masing ingin berkuasa, atau tidak ada pihak yang mau mengalah.

c) Ketepatan respon ini bukan hanya berkenaan dengan pesan-pesan verbal tetapi juga dengan pesan non verbal.

d) Suasana emosional, merupakakan keserasian suasana emosional ketika berlangsungnya komunikasi. Walaupun mungkin saja terjadi dua orang berinteraksi dengan suasana emosional yang berbeda, tetapi interaksi itu tidak akan stabil. Besar kemungkinan salah satu pihak mengakhiri interaksi atau mengubah suasana emosinya. ${ }^{8}$

3) Pemutusan hubungan

Hubungan sosial yang terjadi antara individu tidak selalu berjalan dengan lancar seperti apa yang kita harapkan. Hal ini disebabkan karena perbedaan antara masing-masing individu baik dalam segi pemikiran maupun dari segi kepribadian. Perbedaan tersebut dapat menjadi salah satu faktor pemicu putusnya hubungan sosial.

\section{c. Bentuk-Bentuk Hubungan Sosial}

1) Hubungan sosial asosiatif

Hubungan ini merupakan hubungan yang bersifat positif, artinya hubungan ini dapat mempererat jalinan atau solidaritas kelompok. Hubungan ini terjadi apabila seseorang atau sekelompok orang melakukan interaksi sosial yang memiliki persamaan pandangan dan tindakan, sehingga mengarah pada satu tujuan. Adapun ciri-ciri hubungan sosial yang baik menurut Abraham Maslow adalah sebagai berikut:

a) Inclusion (keinginan)

b) Control (pengendalian)

c) Afection (perasaan)

2) Akomodasi

${ }^{8}$ Ibid, h. 129. 
Menurut Soerjono Soekanto, bentuk-berntuk akomodasi itu adalah sebagai berikut:

a) Coercion merupakan suatu bentuk akomodasi yang prosesnya dilaksanakan oleh karena adanya paksaan.

b) Compromise merupakan suatu bentuk akomodasai dimana pihakpihak yang terlibat saling mengurangi tuntutannya sehingga mencapai suatu penyelesaian terhadap perselisihan yang ada.

c) Conciliation yang mempertemukan keinginan di pihak yang berselisih demi tercapainya persetujuan bersama.

d) Toleration merupakan akomodasi tanpa persetujuan folmal.

e) Stralemate merupakan akomodasi dimana pihak yang bertentangan karena mempunyai kekuatan yang seimbang berhenti pada titik tertentu dalam pertentangan. ${ }^{9}$

3) Asimilasi

Asimilasi merupakan proses sosial dalam taraf lanjut. Ia ditandai dengan adanya usaha-usaha mengurangi perbedaan yang terdapat antara orang perorangan atau kelompok-kelompok manusia dan juga meliputi usaha-usaha, mempertinggi kesatuan tindak, sikap dan proses mental memperhatikan kepentingan-kepentingan dan tujuan bersama.

4) Hubungan sosial disosiatif

Hubungan social disosiatif merupakan hubungan sosial yang mengarah kepada hubungan negatif. Hubungan sosial disosiatif ini dibedakan dalam tiga bentuk yaitu.

a) Persaingan (Competition)

b) Kontraversi (Kontraversion)

c) Pertentangan (Conflict)

\section{d. Faktor-Faktor yang Mempengaruhi Hubungan Sosial}

Enung Fatimah mengemukakan bahwa "hubungan sosial dipengaruhi oleh faktor, antara lain adalah keluarga, kematangan, status sosial ekonomi, tingkat pendidikan dan kemampuan mental,

${ }^{9}$ Soekanto, Mengenal Tujuh Tokoh, h. 70-71. 
terutama emosi dan intelegensi". ${ }^{10}$ Berdasarkan kutipan di samping, selanjutnya penulis akan menjabarkanya secara lebih luas.

1) Keluarga

2) Kematangan

3) Status sosial ekonomi

4) Pendidikan

5) Emosi dan intelegensi

\section{e. Pengertian Konseling Teman Sebaya}

Konseling teman sebaya merupakan suatu bentuk bantuan yang dilakukan oleh individu yang seusia baik secara perorangan maupun secara berkelompok. Seusia juga bisa diartikan sama-sama pada suatu periodesasi perkembangan tertentu. Misalnya periodesasi perkembangan masa remaja, jadi sebaya yang dimaksud adalah sesama remaja. Jika masa dewasa, maka sebaya yang dimaksud adalah sesama dewasa, sedangkan masa tua, maka sebayanya adalah seseorang yang usianya tua. Konseling teman sebaya merupakan proses konseling yang dalam teman sebaya. Menurut Suwarjo "konseling teman sebaya adalah konseling antara konselor ahli dengan konseli dengan menggunakan perantara teman sebaya (konselor sebaya) dari pada konseli (counseling through peer)."11

\section{f. Fungsi dan Tujuan Konseling Teman Sebaya di Perguruan Tinggi}

Keberadaan bimbingan dan konseling di perguruan tinggi sangat strategis. Mahasiswa sebagai peserta didik di perguruan tinggi dari segi periodesasi perkembangannya sudah memiliki kematangan usia. Kondisi ini menjadikan mahasiswa mulai menetap pilihan-pilihan dalam kehidupannya, mulai dari persoalan pribadi, hubungan sosial (berkaitan dengan lawan jenis atau hubungan muda mudi), karir dan pekerjaan, pilihan untuk membina hubungan keluarga, serta mengambil peran dalam kehidupan bermasyarakat. Semua itu

\footnotetext{
${ }^{10}$ Fatimah, Psikologi Perkembangan, h. 91.

${ }^{11}$ Suwarjo, Konseling Teman Sebaya (Peer Counseling) untuk Mengembangkan Resiliensi Remaja (Makalah pada Seminar Pengembangan Ilmu Pendidiakn Fakultas Ilmu Pendidikan Universitas Negeri Yogyakarta: 2008), h. 10.
} 
menuntut mahasiswa dalam tugasnya sebagai manusia akademik menjadikan mahasiswa selalu dalam keadaan dilematis. Kondisi dilematis mahasiswa sangat membutuhkan bantuan layanan bimbingan dan konseling.

Secara umun fungsi bimbingan dan konseling yang dikemukakan oleh Ditjen Dikti, adalah: “(a) fungsi pemahaman, (b) fungsi pencegahan, (c) fungsi pengentasan, (d) fungsi pemeliharaan dan pengembangan, (e) fungsi advokasi". ${ }^{12}$

\section{g. Prinsip Konseling Teman Sebaya}

Kontak-kontak yang terjadi dalam konseling teman sebaya dilakukan dengan menggunakan prinsip-prinsip yang dikemukakan oleh Suwarjo yaitu:

1) Informasi (termasuk masalah) yang dibahas dalam sesi-sesi konseling teman sebaya adalah rahasia. Dengan demikian, apa yang dibahas dalam kelompok, dan apa yang dibahas oleh sepasang teman, menjadi rahasia bersama yang tidak boleh dibagikan kepada orang lain;

2) Harapan, hak-hak, nilai-nilai dan keyakinan-keyakinan "konseli" dihormati;

3) Tidak ada penilaian (judgment) dalam sesi konseling teman sebaya;

4) Pemberian informasi dapat menjadi bagian dari konseling teman sebaya, sedangkan pemberian nasehat tidak;

5) Teman yang dibantu ("konseli") bebas untuk membuat pilihan, dan kapan akan mengakhiri sesi;

6) Konseling teman sebaya dilakukan atas dasar kesetaraan (equality);

7) Setiap saat "konseli" membutuhkan dukungan yang tidak dapat dipahami melalui konseling teman sebaya, dia dialihtangankan kepada konselor ahli, lembaga, atau organisasi yang lebih tepat;

8) Kapanpun membutuhkan, "konseli" memperoleh informasi yang jelas tentang konseling teman sebaya, tujuan, proses, dan teknik 15-16.

${ }^{12}$ Dikjen Dikti, Dasar Standardisasi Profesi Konseling (Jakarta: Depdiknas, 2004), h. 
yang digunakan dalam konseling teman sebaya sebelum mereka memanfaatkan layanan tersebut. ${ }^{13}$

\section{Tujuan Penelitian}

Berdasarkan identifikasi diatas maka yang menjadi tujuan penelitian adalah untuk mengetahui:

a. Mengatasi masalah hubungan sosial mahasiswa melalui konseling teman sebaya.

b. Pengaruh hubungan sosial terhadap hasil belajar mahasiswa.

c. Hubungan sosial ditinjau dari pencapaian tugas perkembangan Mahasiswa dan rumusan program pengembangannya.

\section{B. METODOLOGI}

\section{Metode Penelitian}

Adapun jenis penelitian yang penulis gunakan adalah eksperimen. Penelitian eksperimen adalah "suatu model penelitian, dimana peneliti memanipulasi suatu stimuli atau kondisi, kemudian mengobservasi pengaruh atau akibat dari perubahan stimuli atau kondisi tersebut pada objek yang dikenai stimuli atau kondisi tersebut". ${ }^{14}$ Adapun model eksperimen yang dipakai adalah quasi eksperimen (ekpserimen semu). Menurut Moh Kasiram, quasi eksperimen yaitu:

"Desain eksperimen yang memungkinkan peneliti mengendalikan variabel sebanyak mungkin dari situasi yang ada, namun desain ini tidak mengendalikan variabel secara penuh seperti pada eksperimen sebenarnya, namun peneliti bisa memperhitungkan variabel apa saja yang tidak mungkin dikendalikan ${ }^{15}$.

${ }^{13}$ Suwarjo, Konseling Teman Sebaya, h. 11-12.

${ }^{14}$ Moh. Kasiram, Metodologi Penelitian: Refleksi Pengembangan Pemahaman dan Penguasaan Metodologi Penelitian (Malang: UIN MALIKI Press, 2008), h. 210.

15 Ibid, h. 214. 
Berdasarkan pendapat di atas dapat penulis jelaskan, bahwa alasan peneliti memilih menggunakan quasi eksperimen karena tidak semua variabel luar bisa dikendalikan. Mengingat dalam penelitian ini peneliti mengukur gejala sosial yang cenderung selalu berubah sehingga tidak semua gejala itu bisa dikontrol oleh peneliti. Adapun desain eksperimen semu yang peneliti pakai yaitu pre-test-post-testcontrol-group design.

Pada penelitian ini penulis akan menggunakan penelitian quasi experiment dengan model randomized control group pre-test-post-test design. Penelitian dalam model ini dilakukan dengan cara, "sebelum melakukan perlakuan kedua kelompok diberi perlakuan atau pretest untuk mengukur kondisi awal $\left(\mathrm{O}_{1}\right)$. Selanjutnya pada kelompok eksperimen diberi perlakuan $(\mathrm{X})$ dan pada kelompok pembanding tidak diberi perlakuan. Sesudah selesai penelitian kedua kelompok diberi test lagi sebagai posttets $\left(\mathrm{O}_{2}\right)$ " ${ }^{16}$.

Selanjutnya pada kelompok eksperimen diberi perlakuan dan pada kelompok pembanding tidak diberi. Sesudah selesai penelitian kedua kelompok diberi test lagi sebagai post tes $\left(0_{2}\right)^{\text {"17 }}$. Apabila digambarkan adalah sebagai berikut ini:

Model Eksperimen

\begin{tabular}{|l|c|c|c|}
\hline \multicolumn{1}{|c|}{ R Group } & Pre test & Treatmen & Post test \\
\hline Eksperimen & 01 & $\mathrm{X}$ & 02 \\
\hline Kontrol & 01 & - & 02 \\
\hline
\end{tabular}

Maksudnya pada penelitian ini peneliti akan melakukan penelitian kepada sekelompok sampel, dimana sampel tersebut sudah dibagi dalam dua kelompok yaitu sebagai kelompok kontrol dan sebagai kelompok eksperimen. Tapi sebelum kelompok eksperimen diberi perlakuan atau tindakan, maka kedua kelompok terlebih dahulu diberi tes, untuk melihat kondisi masing-masing kelompok, setelah itu baru diberikan treatmen kepada kelompok eksperimen dan kemudian

\footnotetext{
${ }^{16}$ Suharsimi Arikunto, Manajemen Penelitian (Jakarta: PT Rineka Cipta, 2009), h. 210.

${ }^{17}$ Ibid, h. 210.
} 
diberikan tes kembali, dan hasilnya dibedakan dengan hasil tes pertama. Secara umum langkah-langkah untuk melaksanakan penelitian eksperimen adalah:

1) Melakukan Pre-test, yaitu memberikan test berupa pertanyaan tentang hubungan sosial .

2) Melakukan Treatmen, yaitu memberikan perlakuan yaitu layanan konseling teman sebaya kepada kelompok eksperimen.

3) Memberikan Posttest setelah perlakuan diberikan (layanan konseling teman sebaya), lalu diberikan postest kepada kedua kelompok, kelompok eksperimen dan kelompok kontrol.

\section{Hipotesis Penelitian}

Rumusan hipotesis

1. Hipotesis nihil (Ho) adalah layanan konseling teman sebaya tidak dapat mengatasi masalah hubungan sosial mahasiswa secara signifikan.

2. Hipotesis alternatif $(\mathrm{Hl})$ adalah layanan konseling teman sebaya dapat mengatasi masalah hubungan sosial mahasiswa secara sigknifikan.

\section{PEMBAHASAN}

\section{Hasil Penelitian}

Penelitian eksperimen merupakan penelitian yang bertujuan untuk melihat sejauh mana suatu variabel dapat ditingkatkan setelah diberi perlakuan. Penelitian yang penulis lakukan adalah untuk melihat signifikan atau tidaknya mengatasi masalah hubungan sosial mahasiswa melalui layanan konseling teman sebaya.

Data tentang mahasiswa yang bermasalah dengan hubungan sosial diperoleh dari hasil wawancara penulis dengan mahasiswa. Terkait dengan permasalahan hubungan sosial, maka penulis akan menyajikan hasil penelitian yang mengungkap tentang kondisi hubungan sosial mahasiswa dan sejauh mana layanan konseling teman sebaya mampu mengatasi masalah hubungan sosial mahasiswa. Untuk mengawali kegiatan penelitian, maka penulis menyebarkan angket untuk mengungkap kondisi awal. 
Setelah membagi siswa menjadi dua kelompok, dan menghitung jumlah skor hubungan sosial maka langkah selanjutnya yang peneliti lakukan adalah pengklasifikasian skor jawaban mahasiswa sekaligus menghitung berapa persen mahasiswa yang tergolong pada ketegori hubungan sosial tertentu. Adapun data tentang hubungan sosial mahasiswa tergambar pada tabel berikut:

Interval Hubungan Sosial

\begin{tabular}{|c|c|c|c|c|}
\hline No & Kategori & Skor & F & \% \\
\hline 1 & Sangat Baik & $\geqslant 147$ & 0 & 0 \\
\hline 2 & Baik & $119-146$ & 7 & 35 \\
\hline 3 & Kurang Baik & $91-118$ & 13 & 65 \\
\hline 4 & Tidak Baik & $63-90$ & 0 & 0 \\
\hline 5 & Sangat Tidak Baik & $35-62$ & 0 & 0 \\
\hline \multicolumn{4}{|c|}{ Jumlah } & 100 \\
\hline
\end{tabular}

Berdasarkan hasil angket pretest tersebut tergambar bahwa mahasiswa memiliki hubungan sosial dengan kategori berada pada posisi baik dan kurang baik, artinya belum semua siswa memiliki hubungan sosial yang baik atau sangat baik. Walaupun demikian kondisi tersebut masih perlu untuk ditingkatkan menjadi lebih baik dari yang sudah ada. Adapun jumlah mahasiswa yang memiliki hubungan sosial yang kategori baik berjumlah 7 orang, yang apabila dirata-ratakan dengan jumlah seluruh mahasiswa yang kategori hubungan sosial belum separoh berada pada kategori baik. Untuk jumlah mahasiswa yang mencapai hubungan sosial pada kategori kurang baik berjumlah 13 orang, artinya lebih separoh dari mahasiswa program KI/BK semester VI ini memiliki hubungan sosial dengan kategori pada posisi kurang baik.

Data hasil pengolahan angket hubungan sosial pada saat pretest dapat dirincikan sebagai berikut:

Hubungan Sosial Mahasiswa Berdasarkan Hasil Pretest

\begin{tabular}{|c|c|c|c|}
\hline No & Kode Mahasiswa & Skor & Kategori Mutu \\
\hline 1 & RI & 96 & Kurang Baik \\
\hline 2 & AH & 91 & Kurang Baik \\
\hline
\end{tabular}




\begin{tabular}{|c|c|c|c|}
\hline 3 & KI & 120 & Baik \\
\hline 4 & LA & 98 & Kurang Baik \\
\hline 5 & SA & 145 & Baik \\
\hline 6 & NA & 127 & Baik \\
\hline 7 & FI & 133 & Baik \\
\hline 8 & AT & 100 & Kurang Baik \\
\hline 9 & MA & 118 & Kurang Baik \\
\hline 10 & NI & 105 & Kurang Baik \\
\hline 11 & RE & 117 & Kurang Baik \\
\hline 12 & BI & 140 & Baik \\
\hline 13 & AX & 91 & Kurang Baik \\
\hline 14 & PS & 94 & Kurang Baik \\
\hline 15 & IJ & 125 & Baik \\
\hline 16 & ET & 115 & Kurang Baik \\
\hline 17 & EN & 110 & Kurang Baik \\
\hline 18 & AN & 92 & Kurang Baik \\
\hline 19 & EL & 108 & Kurang Baik \\
\hline 20 & CI & 145 & Baik \\
\hline
\end{tabular}

Berdasarkan temuan di atas, maka mahasiswa dibagi menjadi dua kelompok yaitu kelompok kontrol dan kelompok eksperimen. Kelompok eksperimen yaitu kelompok yang akan diberikan treatment melalui layanan konseling teman sebaya, sedangkan kelompok kontrol yaitu kelompok yang tidak diberikan treatment, tapi nantinya akan dijadikan sebagai standar pembanding mutu hubungan sosial mahasiswa kelompok eksperimen setelah diberi layanan.

Peneliti membagi mahasiswa ke dalam kelompok eksperimen dan kelompok kontrol dengan cara randomisasi, maksudnya dalam satu kelompok tidak tertutup kemungkinan ada mahasiswa yang memiliki ketegori mutu hubungan sosial kurang baik dan sangat tidak baik, baik itu pada kelompok kontrol maupun kelompok eksperimen. Jadi, yang diberi treatmen bukan saja mahasiswa yang memiliki kategori hubungan sosial tidak baik tetapi, mahasiswa yang memiliki 
penyesuaian diri baik juga perlu untuk ditingkatkan menjadi sangat baik, hasil randomisasi tersebut yaitu:

Anggota Kelompok Kontrol

\begin{tabular}{|c|c|c|c|}
\hline NO & $\begin{array}{c}\text { Kode } \\
\text { Mahasiswa }\end{array}$ & Skor & Ketegori Mutu \\
\hline 1 & RI & 96 & Kurang Baik \\
\hline 2 & AH & 91 & Kurang Baik \\
\hline 3 & SA & 145 & Baik \\
\hline 4 & MA & 118 & Kurang Baik \\
\hline 5 & NI & 105 & Kurang Baik \\
\hline 6 & BI & 140 & Baik \\
\hline 7 & PS & 94 & Kurang Baik \\
\hline 8 & IJ & 125 & Baik \\
\hline 9 & AN & 92 & Kurang Baik \\
\hline 10 & EL & 108 & Kurang Baik \\
\hline
\end{tabular}

Anggota Kelompok Eksperimen

\begin{tabular}{|c|c|c|c|}
\hline NO & $\begin{array}{c}\text { Kode } \\
\text { Mahasiswa }\end{array}$ & Skor & Ketegori Mutu \\
\hline 1 & KI & 120 & Baik \\
\hline 2 & LA & 98 & Kurang Baik \\
\hline 3 & NA & 127 & Baik \\
\hline 4 & FI & 133 & Baik \\
\hline 5 & AT & 100 & Kurang Baik \\
\hline 6 & RE & 117 & Kurang Baik \\
\hline 7 & AX & 91 & Kurang Baik \\
\hline 8 & ET & 115 & Kurang Baik \\
\hline 9 & EN & 110 & Kurang Baik \\
\hline 10 & CI & 145 & Baik \\
\hline
\end{tabular}

\section{Rencana Layanan Konseling Teman Sebaya}

Setelah peneliti menetapkan kelompok eksperimen dan kelompok kontrol maka langkah selanjutnya adalah merencanakan layanan yang akan diberikan. Treatmen hanya diberikan kepada kelompok eksperimen saja, sementara itu kelompok kontrol tidak 
diberi treatment. Kelompok kontrol tidak diberikan treatmen atau layanan konseling teman sebaya karena akan dijadikan sebagai pembanding bagi kelompok eksperimen setelah diberikan layanan. Untuk membandingkan hasil dari perlakuan tersebut nantinya akan diberikanlah angket Posttest. Rencana pelaksanaan layanan konseling teman sebaya adalah sebanyak empat kali pertemuan, secara lebih rinci seperti pada tabel berikut:

Topik Layanan Konseling Teman Sebaya

\begin{tabular}{|l|l|c|}
\hline No & \multicolumn{1}{|c|}{ Materi } & Waktu \\
\hline 1 & Urgensi hubungan social & 02 Mei 2018 \\
\hline 2 & Macam-macam hubungan social & 03 Mei 2018 \\
\hline 3 & $\begin{array}{l}\text { Kiat-Kiat berhubungan sosial } \\
\text { yang baik }\end{array}$ & 04 Mei 2018 \\
\hline 4 & $\begin{array}{l}\text { Faktor-faktor yang } \\
\text { mempengaruhi hubungan social }\end{array}$ & 06 Mie 2018 \\
\hline 5 & $\begin{array}{l}\text { Faktor-faktor yang } \\
\text { mempengaruhi hubungan sosial } \\
\text { khusus pendidikan }\end{array}$ & 07 Mei 2018 \\
\hline 6 & Pentingnya kerjasama & 08 Mei 2018 \\
\hline
\end{tabular}

\section{Pembahasan}

Berdasarkan hasil angket pretest tersebut tergambar bahwa mahasiswa memiliki hubungan sosial dengan kategori berada pada posisi baik dan kurang baik, artinya belum semua siswa memiliki hubungan sosial yang baik atau sangat baik. Walaupun demikian kondisi tersebut masih perlu untuk ditingkatkan menjadi lebih baik dari yang sudah ada. Adapun jumlah mahasiswa yang memiliki hubungan sosial yang kategori baik berjumlah 7 orang, yang apabila dirata-ratakan dengan jumlah seluruh mahasiswa yang kategori hubungan sosial belum separoh berada pada kategori baik. Untuk jumlah mahasiswa yang mencapai hubungan sosial pada kategori kurang baik berjumlah 13 orang, artinya lebih separoh dari mahasiswa ini memiliki hubungan sosial dengan kategori pada posisi kurang baik. 


\section{Pemberian Treatment Berupa Pelaksanaan Layanan Konseling Teman} Sebaya

Konseling teman sebaya merupakan treatment yang diberikan pada kelompok eksperimen. Pelaksanaan layanan Konseling teman sebaya dilakukan dalam bentuk berkelompok sebanyak empat kali. Dengan jumlah anggota sebanyak 10 orang. Pelaksanaannya secara lebih rinci akan diuraikan sebagai berikut:

\section{Treatment I}

Pelaksanaan layanan konseling teman sebaya pertama kali dilakukan melalui tahap-tahap berikut:

\section{a. Tahap Pembukaan}

Pada tahap ini yang lakukan adalah membuka kegiatan dengan memberikan kata sambutan kepada anggota, ucapan selamat datang dan terima kasih atas kesediaannya untuk hadir dan mengikuti kegiatan konseling teman sebaya. Sebelum menjelaskan lebih lanjut, terlebih dahulu dilakukan pemilihan konselor teman sebaya secara suka rela. Kemudian menjelaskan fungsi konselor kepada klien. Dilanjutkan dengan perkenalan dengan menggunakan rangkaian nama agar emosional yang terjalin menjadi lebih dekat dan akrab serta mudah diingat. Dimulai dari KO sebaya:

$\begin{array}{ll}\text { Nama } & \text { : KI } \\ \text { TTL } & \text { : Bungo, 07 -07 } 1999 \\ \text { Alamat } & \text { : Bungo } \\ \text { Hobi } & \text { : Membaca dan Volly }\end{array}$

b. Tahap pelepasan emosi

Pada tahap ini yang lakukan adalah KO mengenali dunia klien dan KO memberikan kesempatan kepada klien untuk menceritan masalah yang sedang dialami. ET menceritakan masalahnya "Ada seseorang yang menyukai klien tapi klien tidak menyukai orang tersebut, klien memberi alasan ia tidak akan berpacaran sebelum tamat kuliah. Tidak lama kemudian klien menyukai kakak orang yang menyukainya. kemudian hubungan sosial mereka mulai kurang baik" c. Tahap pengembangan ke arah rasional

Pada tahap ini yang lakukan adalah KO memancing agar klien menyebutkan altenatif pemecahan masalah yang dialaminya.dan 
anggota kelompok saling berebutan untuk menyampaikan pendapatnya. Diantaranya:

RI: Adiknya sudah tahu belum kalau ET menyukai kakaknya?

LA: Komunikasi ET sama adiknya sekarang bagaimana?

CI: Bicara saja baik-baik sama adiknya kalau saudara menyukai kakanya?

KO: Apa keinginan ET ingin tetap menjalani hubungan sama kakaknya atau tetap ingin berpegang pada komitmen ET?

Pada tahap ini KO mengaitkan masalah klien dengan materi urgensi hubungan sosial .

d. Tahap penutup

Pada tahap ini yang dilakukan adalah pengambilan keputusan. Dimana ET mengambil keputusan atas kesadarannya sendiri. ET memilih untuk tidak menjalin hubungan pacaran sama kakak dan juga sama adiknya, ET akan tetap akan menjalin hubunga sosial yang baik seperti biasanya. ET merasa senang masalahnya bisa terentaskan dan ET dan anggota lainnya juga merasa senang dan bebas dalam menceritakan permasalahannya karena tidak ada rasa takut karena kita sama-sama besar seperti curhat sama teman saja rasanya.

Kemudian KO dan anggota kelompok membuat kontrak untuk kegiatan selanjutnya kegiatan ditutup dengan do'a dan ucapan terima kasih. Berdasarkan treatment I dengan materi Urgensi hubungan sosial maka diperoleh hasil sebagai berikut ini:

Hasil Treatment dengan Meteri Urgensi Hubungan Sosial

\begin{tabular}{|c|c|c|c|c|c|c|}
\hline No & \multirow{2}{*}{$\begin{array}{c}\text { Kode } \\
\text { siswa }\end{array}$} & \multicolumn{2}{|c|}{ Pretest } & \multicolumn{2}{|c|}{ Posttest } & Penamb \\
\cline { 3 - 6 } & & Skor & Katergori & Skor & Kategori & $\begin{array}{c}\text { ahan } \\
\text { skor }\end{array}$ \\
\hline 1 & KI & 118 & Kurang Baik & 124 & Baik & 6 Skor \\
\hline 2 & LA & 147 & Baik & 148 & Baik & 1 Skor \\
\hline 3 & NA & 118 & Kurang Baik & 120 & Baik & 2 Skor \\
\hline 4 & FI & 145 & Baik & 149 & Sangat Baik & 4 Skor \\
\hline 5 & AT & 117 & Kurang Baik & 120 & Baik & 3 Skor \\
\hline 6 & RE & 146 & Baik & 147 & Sangat Baik & 1 Skor \\
\hline 7 & AX & 116 & Kurang Baik & 123 & Baik & 8 Skor \\
\hline
\end{tabular}




\begin{tabular}{|c|c|c|c|c|c|c|}
\hline 8 & ET & 118 & Kurang Baik & 120 & Baik & 2 Skor \\
\hline 9 & EN & 115 & Kurang Baik & 119 & Baik & 4 Skor \\
\hline 10 & CI & 146 & Baik & 148 & Sangat Baik & 2 Skor \\
\hline
\end{tabular}

\section{Treatment II}

Pada tahap ini yang dilakukan adalah pengambilan keputusan. Dimana RE mengambil keputusan atas keinginannya sendiri. RE akan bicara baik-baik dengan temannya RE yang selama ini merasa dimanfaatkan ya karena RE sering minta tolong sama teman ketika teman RE sedang sibuk jadi teman RE kadang-kadang ya bisa membantu RE kadang-kadang tidak. RE akan mulai untuk memulai pembiacaraan jika teman-temannya diam karena RE termasuk orang yang pendiam. RE merasa senang dan lega karena selama ini RE sulit untuk mencaritakan masalahnya pada orang lain. RE kalau bisa seringsering saja kita mengadakan konseling teman sebaya karena kita bebas dalam berpandapat dan menceritakan masalah terkadang kalau sama orang tua merasa takut dan malu.

Kemudian KO dan anggota kelompok membuat kontrak untuk Selanjutnya kegiatan ditutup dengan do'a dan ucapan terima kasih. Berdasarkan treatment II dengan materi macam-macam hubungan sosial maka diperoleh hasil sebagai berikut ini:

Hasil Treatment dengan Meteri Macam-Macam Hubungan Sosial

\begin{tabular}{|c|c|c|c|c|c|c|}
\hline \multirow{2}{*}{ No } & \multirow{2}{*}{$\begin{array}{c}\text { Kode } \\
\text { siswa }\end{array}$} & \multicolumn{2}{|c|}{ Pretest } & \multicolumn{2}{|c|}{ Posttest } & Penamb \\
\cline { 3 - 6 } & & Skor & Katergori & Skor & Kategori & $\begin{array}{c}\text { ahan } \\
\text { skor }\end{array}$ \\
\hline 1 & KI & 145 & Baik & 150 & Sangat Baik & 5 Skor \\
\hline 2 & LA & 115 & Kurang Baik & 119 & Baik & 4 Skor \\
\hline 3 & NA & 118 & Kurang Baik & 121 & Baik & 3 Skor \\
\hline 4 & FI & 117 & Kurang Baik & 123 & Baik & 6 Skor \\
\hline 5 & AT & 144 & Baik & 152 & Sangat Baik & 8 Skor \\
\hline 6 & RE & 135 & Baik & 137 & Baik & 2 Skor \\
\hline 7 & AX & 146 & Baik & 150 & Sangat Baik & 4 Skor \\
\hline 8 & ET & 117 & Kurang Baik & 123 & Baik & 5 Skor \\
\hline 9 & EN & 118 & Kurang Baik & 120 & Baik & 2 Skor \\
\hline
\end{tabular}




\begin{tabular}{|l|l|l|l|l|l|l|}
\hline 10 & CI & 135 & Baik & 140 & Baik & 5 Skor \\
\hline
\end{tabular}

\section{Treatment III}

Pada tahap ini yang dilakukan adalah pengambilan keputusan. Dimana AT mengambil keputusan atas keinginannya sendiri. AT tidak akan mengulangi perbuatan buruknya itu, AT akan selalu berusaha untuk peduli terhadap lingkungannya, dan AT juga akan minta maaf sama teman-teman sekosnya. AT merasa senang dan lega karena selama ini AT sulit untuk menceritakan masalahnya pada orang lain. AT kalau bisa sering-sering saja kita mengadakan konseling teman sebaya karena kita bebas dalam berpendapat dan menceritakan masalah terkadang kalau sama orang tua merasa takut dan malu.

Kemudian KO dan anggota kelompok membuat kontrak untuk selanjutnya kegiatan ditutup dengan do'a dan ucapan terima kasih. Berdasarkan treatment III dengan materi kiat-kiat berhubungan sosial yang baik maka diperoleh hasil sebagai berikut ini:

Hasil Treatment dengan Meteri Kiat-Kiat

Berhubungan Sosial yang Baik

\begin{tabular}{|c|c|c|c|c|c|c|}
\hline \multirow{2}{*}{ No } & \multirow{2}{*}{$\begin{array}{l}\text { Kode } \\
\text { siswa }\end{array}$} & \multicolumn{2}{|r|}{ Pretest } & \multicolumn{2}{|c|}{ Posttest } & \multirow{2}{*}{$\begin{array}{c}\text { Penamb } \\
\text { ahan } \\
\text { skor }\end{array}$} \\
\hline & & Skor & Katergori & Skor & Kategori & \\
\hline 1 & $\mathrm{KI}$ & 132 & Baik & 135 & Baik & 3 Skor \\
\hline 2 & LA & 145 & Baik & 157 & Sangat Baik & 2 Skor \\
\hline 3 & NA & 146 & Baik & 151 & Sangat Baik & 5 Skor \\
\hline 4 & FI & 118 & Kurang Baik & 120 & Baik & 2 Skor \\
\hline 5 & $\mathrm{AT}$ & 117 & Kurang Baik & 121 & Baik & 4 Skor \\
\hline 6 & $\mathrm{RE}$ & 118 & Kurang Baik & 119 & Baik & 1 Skor \\
\hline 7 & $\mathrm{AX}$ & 115 & Kurang Baik & 123 & Baik & 8 Skor \\
\hline 8 & ET & 142 & Baik & 146 & Baik & 4 Skor \\
\hline 9 & EN & 111 & Kurang Baik & 119 & Baik & 8 Skor \\
\hline 10 & $\mathrm{CI}$ & 145 & Baik & 147 & Sangat Baik & 2 Skor \\
\hline
\end{tabular}




\section{Treatment IV}

Pada tahap ini yang dilakukan adalah pengambilan keputusan. Dimana LA mengambil keputusan atas keinginannya sendiri. LA akan memperbaiki kesalahan selama ini dan LA akan bicara sama anggota keluarga karena betapa petingnya kebersamaan dalam suatu keluarga. LA merasa senang dan lega karena LA menemukan cara bagaimana membangun kebersamaan dalam keluarganya. Semua anggota kelompok merasa senang karena dalam pelaksanaan konseling teman sebaya mereka merasa bebas dalam mengemukakan pendapat. Dan anggota kelompok mengerti faktor-faktor apa saja yang mempengaruhi hubungan sosial. Selanjutnya kegiatan ditutup dengan do'a dan ucapan terima kasih. Kemudian KO dan anggota kelompok membuat kontrak untuk kegiatan selanjutnya Berdasarkan treatment $I V$ dengan materi faktor-faktor yang mempengaruhi hubungan sosial maka diperoleh hasil sebagai berikut ini :

Hasil Treatment dengan Materi Faktor-Faktor yang Mempengaruhi Hubungan Sosial

\begin{tabular}{|c|c|c|c|c|c|c|}
\hline \multirow[b]{2}{*}{ No } & \multirow{2}{*}{$\begin{array}{l}\text { Kode } \\
\text { siswa }\end{array}$} & \multicolumn{2}{|r|}{ Pretest } & \multicolumn{2}{|c|}{ Posttest } & \multirow{2}{*}{$\begin{array}{c}\text { Penamb } \\
\text { ahan } \\
\text { skor }\end{array}$} \\
\hline & & Skor & Katergori & Skor & Kategori & \\
\hline 1 & $\mathrm{KI}$ & 146 & Baik & 147 & Sangat Baik & 4 Skor \\
\hline 2 & LA & 115 & Kurang Baik & 122 & Baik & 7 Skor \\
\hline 3 & NA & 118 & Kurang Baik & 123 & Baik & 5 Skor \\
\hline 4 & FI & 146 & Baik & 149 & Sangat Baik & 3 Skor \\
\hline 5 & $\mathrm{AT}$ & 117 & Kurang Baik & 120 & Baik & 3 Skor \\
\hline 6 & $\mathrm{RE}$ & 146 & Baik & 150 & Sangat Baik & 4 Skor \\
\hline 7 & $\mathrm{AX}$ & 145 & Baik & 148 & Sangat Baik & 3 Skor \\
\hline 8 & ET & 143 & Baik & 149 & Sangat Baik & 6 Skor \\
\hline 9 & EN & 145 & Baik & 152 & Sangat Baik & 7 Skor \\
\hline 10 & CI & 117 & Kurang Baik & 121 & Baik & 4 Skor \\
\hline
\end{tabular}




\section{Treatment $V$}

Pada tahap ini yang dilakukan adalah pengambilan keputusan. Dimana CI mengambil keputusan atas keinginanya sendiri. Jika mereka masih mengatakan CI seperti itu lagi CI akan berusaha untuk memberikan pemahaman pentingnya pendidin kepada mereka. Apa yang dikatakan mereka akan CI jadikan batu lancatan untuk menjadi orang sukses dan CI harus pulang dengan memperoleh gelar sarjana. CI merasa senang karena masalah yang diutarakannya ditanggapi oleh teman-temannya dengan baik dan CI merasa masalahnya terasa berkurang. Semua anggota konseling teman sebaya merasa senang dan asik karena mereka tidak malu-malu dalam mengemukakan pendapatnya. Dan anggota kelompok mengerti faktor-faktor yang mempengaruhi hubungan sosial salah satunya adalah pendidikan.

Selanjutnya kegiatan ditutup dengan do'a dan ucapan terima kasih. Kemudian KO dan anggota kelompok membuat kontrak untuk kegiatan selanjutnya Berdasarkan treatment $V$ dengan materi faktorfaktor yang mempengaruhi hubungan sosial khusus pendidikan maka diperoleh hasil sebagai berikut ini:

Hasil Treatment dengan Materi Faktor-Faktor yang Mempengaruhi Hubungan Sosial Khusus Pendidikan

\begin{tabular}{|c|c|c|c|c|c|c|}
\hline \multirow{2}{*}{ No } & \multirow{2}{*}{$\begin{array}{l}\text { Kode } \\
\text { siswa }\end{array}$} & \multicolumn{2}{|r|}{ Pretest } & \multicolumn{2}{|c|}{ Posttest } & \multirow{2}{*}{$\begin{array}{c}\text { Penamb } \\
\text { ahan } \\
\text { skor }\end{array}$} \\
\hline & & Skor & Kategori & Skor & Kategori & \\
\hline 1 & $\mathrm{KI}$ & 146 & Baik & 152 & Sangat Baik & 6 Skor \\
\hline 2 & LA & 116 & Kurang Baik & 121 & Baik & 5 Skor \\
\hline 3 & NA & 145 & Baik & 148 & Sangat Baik & 3 Skor \\
\hline 4 & FI & 146 & Baik & 147 & Sangat Baik & 1 Skor \\
\hline 5 & $\mathrm{AT}$ & 118 & Kurang Baik & 120 & Baik & 2 Skor \\
\hline 6 & $\mathrm{RE}$ & 145 & Baik & 153 & Sangat Baik & 8 Skor \\
\hline 7 & $\mathrm{AX}$ & 144 & Baik & 153 & Sangat Baik & 9 Skor \\
\hline 8 & ET & 146 & Baik & & Sangat Baik & 3 Skor \\
\hline 9 & EN & 137 & Baik & 139 & Baik & 2 Skor \\
\hline 10 & $\mathrm{CI}$ & 145 & Baik & 151 & Sangat Baik & 6 Skor \\
\hline
\end{tabular}




\section{Treatment VI}

Pada tahap ini yang dilakukan adalah pengambilan keputusan. Dimana NA mengambil keputusan atas keinginannya sendiri. NA merasa senang dan lega karena selama ini NA sulit untuk menceritakan masalah ini pada orang lain. NA akan berbicara kepada temannya adan NA akan mengajak temannya selalu untuk berkerjasama, memberikan informasi terbaru secepatnya, serta saling membantu disaat salah satu diantara kami mengelami kesulitan dalam mengerjakan tugas dan lain sebagainya. Semua anggota konseling teman sebaya merasa senang dan asik karena mereka bebas dalam mengemukakan pendapatnya tidak ada yang malu-malu dan merasa diseganai. Dan anggota kelompok mengerti tentang pentingnya kerjasama. Selanjutnya kegiatan ditutup dengan do'a dan ucapan terima kasih. Berdasarkan treatment VI dengan materi Pentingnya kerjasama maka diperoleh hasil sebagai berikut ini:

Hasil Treatment dengan Materi Pentingnya Kerjasama

\begin{tabular}{|c|c|c|c|c|c|c|}
\hline \multirow{2}{*}{ No } & \multirow{2}{*}{$\begin{array}{c}\text { Kode } \\
\text { siswa }\end{array}$} & \multicolumn{2}{|c|}{ Sketest } & \multicolumn{2}{|c|}{ Posttest } & Penamb \\
\cline { 3 - 6 } & & Katergori & Skor & Kategori & $\begin{array}{c}\text { ahan } \\
\text { skor }\end{array}$ \\
\hline 1 & KI & 143 & Baik & 147 & Sangat Baik & 4 Skor \\
\hline 2 & LA & 141 & Baik & 148 & Sangat Baik & 7 Skor \\
\hline 3 & NA & 145 & Baik & 149 & Sangat Baik & 4 Skor \\
\hline 4 & FI & 116 & Kurang Baik & 124 & Baik & 8 Skor \\
\hline 5 & AT & 145 & Baik & 148 & Sangat Baik & 3 Skor \\
\hline 6 & RE & 117 & Kurang Baik & 122 & Baik & 5 Skor \\
\hline 7 & AX & 146 & Baik & 148 & Sangat Baik & 2 Skor \\
\hline 8 & ET & 115 & Kurang Baik & 121 & Baik & 6 Skor \\
\hline 9 & EN & 144 & Baik & 150 & Sangat Baik & 6 Skor \\
\hline 10 & CI & 146 & Baik & 149 & Sangat Baik & 3 Skor \\
\hline
\end{tabular}


Dari tahap-tahap tersebut maka hasil Pemberian Post-Test sebagai berikut:

Perbandingan Skor Pre-Test dan Post-Test Kelompok Kelompok

Eksperimen

\begin{tabular}{|c|c|c|c|c|c|c|}
\hline \multirow{2}{*}{ No } & \multirow{2}{*}{$\begin{array}{l}\text { Kode } \\
\text { Maha } \\
\text { siswa }\end{array}$} & \multicolumn{2}{|c|}{ Pretest } & \multicolumn{2}{|c|}{ Posttest } & \multirow{2}{*}{$\begin{array}{c}\text { Ketera } \\
\text { ngan }\end{array}$} \\
\hline & & Skor & Kategori & Skor & Kategori & \\
\hline 1 & KI & 120 & Baik & 148 & Sangat Baik & Naik 28 \\
\hline 2 & LA & 98 & Kurang Baik & 124 & Baik & Naik 26 \\
\hline 3 & NA & 127 & Baik & 149 & Sangat Baik & Naik 22 \\
\hline 4 & FI & 133 & Baik & 157 & Sangat Baik & Naik 24 \\
\hline 5 & $\mathrm{AT}$ & 100 & Kurang Baik & 123 & Baik & Naik 23 \\
\hline 6 & $\mathrm{RE}$ & 117 & Kurang Baik & 138 & Baik & Naik 21 \\
\hline 7 & $\mathrm{AX}$ & 91 & Kurang Baik & 123 & Baik & Naik 32 \\
\hline 8 & ET & 115 & Kurang Baik & 141 & Baik & Naik 26 \\
\hline 9 & EN & 110 & Kurang Baik & 139 & Baik & Naik 29 \\
\hline 10 & $\mathrm{CI}$ & 145 & Baik & 167 & Sangat Baik & Naik 22 \\
\hline \multicolumn{2}{|c|}{ Jumlah } & 1156 & - & 1409 & - & \multirow[t]{2}{*}{253} \\
\hline \multicolumn{2}{|c|}{ Rata-rata } & 115,6 & - & 140,9 & - & \\
\hline
\end{tabular}

Berdasarkan tabel di atas, dapat dilihat perbandingan skor pada kelompok eksperimen sebelum dan sesudah diberikan perlakuan (treatment), yaitu pada mahasiswa KI terjadi kenaikan skor sebesar 28, LA naik 26 skor, NA naik 22 skor, FI naik 24 skor, AT naik 23 skor, RE naik 21 skor, AX naik 32 skor, ET naik 26 skor, EN naik 29 skor, dan CI naik 22 skor.

Berdasarkan penjelasan di atas, ditemukan adanya perubahan skor yang dialami oleh responden pada kelompok eksperimen. Peningkatan yang terjadi terlihat dari perubahan rata-rata skor kelompok eksperimen yang semula 115,6 sebelum diberikan perlakuan menjadi 140,9 sehingga terjadi peningkatan sebesar 25,3. 


\section{Analisis Data dengan Rumus Statistik (Uji t)}

Adapun langkah-langkah dalam menganalisa data dengan model sampel kecil ini adalah.

1. Menyiapkan Tabel Perhitungannya.

Analisa Data dengan Statistik (Uji t)

\begin{tabular}{|c|c|c|c|c|l|l|}
\hline No & $\mathbf{X}_{1(\mathrm{ekp})}$ & $\left(\mathbf{X}_{1}-\mathbf{X}\right)$ & $\left(\mathbf{X}_{1}{ }^{2}\right)$ & $\mathbf{X}_{2(\mathrm{ktrl})}$ & $\left(\mathbf{X}-\mathbf{X}_{2}\right)$ & \multicolumn{1}{|c|}{$\left(\mathbf{X}^{2}{ }^{2}\right)$} \\
\hline 1 & 148 & 7,1 & 50,41 & 102 & $-13,3$ & 176,89 \\
\hline 2 & 124 & $-16,9$ & 285,61 & 95 & $-20,3$ & 412,09 \\
\hline 3 & 149 & 8,1 & 65,61 & 146 & 30,7 & 942,49 \\
\hline 4 & 157 & 16,1 & 259,21 & 118 & 2,7 & 7,29 \\
\hline 5 & 123 & $-17,9$ & 320,41 & 108 & $-7,3$ & 53,29 \\
\hline 6 & 138 & $-2,9$ & 8,41 & 145 & 29,7 & 882,09 \\
\hline 7 & 123 & $-17,9$ & 320,41 & 101 & $-14,3$ & 204,49 \\
\hline 8 & 141 & 0,01 & 0,01 & 130 & 14,7 & 216,09 \\
\hline 9 & 139 & $-1,9$ & 3,61 & 100 & $-15,3$ & 234,09 \\
\hline 10 & 167 & 26,1 & 681,21 & 108 & $-7,3$ & 53,29 \\
\hline JML & 1409 & & $\sum \mathbf{X}_{1}{ }^{2}=$ & 1153 & & $\sum \mathbf{X}_{2}{ }^{2}=$ \\
\hline AVR & 140,9 & & 1994,9 & 115,3 & & 3182,1 \\
\hline
\end{tabular}

Mencari Mean dari masing-masing kelompok (Eksperimen dan Kontrol)

Mencari $\mathrm{M}_{1}$ (kelompok eksperimen) $=\frac{\sum X 1}{N}=\frac{1409}{10}=140,9$.

Mencari $\mathrm{M}_{2}$ (kelompok kontrol) $=\quad M_{2}=\frac{\sum x_{2}}{N}=\frac{1153}{10}=115,3$

Mencari deviasi standar dari masing-masing kelompok

a. Deviasi Standar kelompok eksperimen dan kontrol

$$
\begin{aligned}
& \operatorname{SDX}_{1}=\sqrt{\frac{\sum X 1^{2}}{N}}=\sqrt{\frac{1994,9}{10}}=\sqrt{199,49}=14,12 \\
& \mathrm{SDX}_{2}=\sqrt{\frac{\sum_{X_{2}} 2}{N}}=\sqrt{\frac{318, \mathrm{x}}{10}}=\sqrt{318,21}=17,83
\end{aligned}
$$

b. Mencari standar error

a) Standar error kelompok eksperimen 


$$
S E_{M 1}=\frac{S D_{X 1}}{\sqrt{N-1}}=\frac{14,12}{3}=4,70
$$

b) Standar error kelompok kontrol

$$
S E_{M 2}=\frac{S D_{X 2}}{\sqrt{N-1}}=\frac{17,83}{3}=5,94
$$

Standar error M1-M2

$$
\begin{aligned}
& =\sqrt{S E_{M 1}{ }^{2}+S E_{M 2}{ }^{2}} \\
& =\sqrt{4,70+5,94^{2}}=\sqrt{22,09+35,28}=\sqrt{57,37}=7,57
\end{aligned}
$$

c. Mencari harga $t_{0}$ dengan rumus sebagai berikut ini:

$$
\begin{gathered}
\mathrm{t}=\frac{M_{1}-M_{2}}{S E_{M 1-M 2}} \\
\mathrm{t}=\frac{140,9-115,6}{7,57}=\frac{25,3}{7,57}=3,34 \\
\text { d. } \quad \mathrm{df}=\left(\mathrm{N}_{1}+\mathrm{N}_{2}\right)-2 \\
=(10+10)-2
\end{gathered}
$$$$
=18
$$

Berdasarkan hasil analisis data statistik di atas maka didapatlah bahwa harga " $t$ " hitung sebanyak 3,34 dengan df atau db 18. Maka apabila konsultasi pada tabel Nilai $t$, taraf 1\% maka diperolehlah harga kritik $t$ sebesar 2,90. Kemudian dengan membandingkan hasil dari t hitung $\left(t_{0}\right)$ dengan $t$ tabel $\left(t_{t}\right)$, maka dapat dianalisis bahwa $t_{0}$ lebih besar dari $t_{t}$, pada taraf signifikansi 1\% yaitu: 3,34 > dari 2,90.

Berdasarkan hasil perhitungan statistik maka dapat disimpulkan hipotesis nihil $\left(h_{0}\right)$ yang menyatakan bahwa layanan konseling teman sebaya tidak dapat mengatasi masalah hubungan sosial mahasiswa ditolak. Dan hipotesis alternatif (ha) yang menyatakan bahwa layanan konseling teman sebaya dapat mengatasi masalah hubungan sosial mahasiswa diterima. Artinya layanan konseling teman sebaya dapat mengatasi masalah hubungan sosial mahasiswa pada taraf signifikansi $1 \%$. 


\section{PENUTUP}

Berdasarkan hasil penelitian tentang mengatasi masalah hubungan sosial mahasiswa dapat disimpulkan bahwa dari 6 kali pelaksanaan treatment konseling teman sebaya bahwa anggota konseling teman sebaya merasa senang dan lega setelah mengikuti layanan konseling teman sebaya mereka merasa masalah yang dihadapinya terasa berkurang. Dalam pelaksanaan konseling teman sebaya anggota kelompok merasa lebih terbuka dan bebas dalam mengemukakan pendapat.

\section{Daftar Pustaka}

Achmad Juntika Nurihsan, Bimbingan dan Konseling dalam Berbagai Latar Kehidupan, Bandung: Pt. Refika Aditama, 2006.

Anas Sudijono, Pengantar Statistik Pendidikan, Jakarta: PT Raja Grafindo, 2005.

Andi Mapiare, Psikologi Orang Dewasa, Surabaya: Usaha Nasional, 1983.

Ardimen, Implementasi Layanan Bimbingan dan Konseling di Perguruan Tinggi Dikaitkan dengan Kebutuhan Mahasiswa, Tesis, Bandung: PPS UPI, 2000.

Baharuddin, Psikologi Pendidikan Refleksi Teoretis Terhadap Penomena, Yogyakarta: Ar-Ruzz Media, 2007.

Cemara PKBI SUMBAR, Pengantar Konseling, Padang: Makalah, 2010.

Departemen Pendidikan dan Kebudayaan, Kamus Besar Bahasa Indonesia Jakarta: Balai Pustaka, 1990.

Desmita, Psikologi Orang Dewasa, Batusangkar: STAIN Press, 2007.

Dikjen Dikti, Dasar Standardisasi Profesi Konseling, Jakarta: Depdiknas, 2004. 
Englandrea, Hubungan Sosial, (Online), Tersedia: http://ebookbrowse.com/teori-hubungan-sosial-pdfd341746857 (05 Februari 2013)

Enung Fatimah, Psikologi perkembangan (Perkembangan Peserta Didik), Bandung: Pustaka Setia, 2006.

IPBI,Pedoman Umum BTS (Bimbingan Teman Sebaya), Padang: Pengurus Besar IPBI, 2000.

Jalaluddin Rakhmad, Psikologi Komunikasi, Bandung: PT Raja Rosdakarya, 2007.

Kartini Kartono, Patologi Sosial Jakarta: Raja Grafindo, 1999.

Mardalis, Metodologi Penelitian Pendidikan dan Prakteknya, Jakarta: Bumi Aksara, 2004.

Myrick. Robert D, Developmental Guidance and Counseling: A Pratical Approach, Minneapolis: Educational Media Corporation, 2003.

Moh. Kasiram, Metodologi Penelitian: Refleksi Pengembangan Pemahaman dan Penguasaan Metodologi Penelitian, Malang: UIN MALIKI Press, 2008.

Muhammad Ali, dkk, Psikologi Remaja Perkembangan Peserta Didik, Jakarta: Bumi Aksara, 2004.

Munro, dkk, Penyuluhan (Counseling) Suatu Pendekatan Berdasarkan Keterampilan, Jakarta: Ghalia Indonesia, 1983.

Piotr Sztompka, Sosiologi Perubahan Sosial, Jakarta: Prenada Media, 2004.

Philipus, Sosiologi Politik, Jakarta: PT. Raja Grafindo Persada, 2004.

Prayitno dan Erman Amti, Dasar-Dasar Bimbingan Dan Konseling, Jakarta: Rineka Cipta, 1999.

Prayitno, Dasar Standarisasi Prifesi Konseling, Jakarta: Dirjen PT Diknas, 2004. 
Riduwan, Belajar Mudah Penelitian untuk Guru Karyawan dan Peneliti Pemula, Bandung : Alfabeta, 2005.

Sarlito Wirawan Sarwono, Psikologi Sosial Individu dan Teori-Teori Psikologi Sosial, Jakarta: Balai Pustaka, 2002.

Sayekti Pujosuwarno, Bimbingan dan Konseling Keluarga, Yokyakarta: Menara Mas O ffet, 1994.

Soerjono Soekanto, Mengenal Tujuh Tokoh Sosiologi, Jakarta: PT RajaGrafindo Persada, 2011.

S. Eko Putro Widoyoko, Teknik Penyusunan Instrumen Penelitian, Yogyakarta: Pustaka Belajar, 2012.

Sri Rumini dan Siti Sundari, Perkembangan Anak \& Remaja, Jakarta: PT Rineka Cipta, 2004.

Sofyan S. Willis, Konseling Individual Toeri dan Praktek, Bandung: Alfabeta: 2004.

Sugiyono, Metode Penelitian Pendidikan Pendekatan Kuantitatif, Kualitatif dan R\&D, Bandung: Alfabeta, 2007

Suharsimi Arikunto, Manajemen Penelitian, Jakarta: PT Rineka Cipta, 2009.

Suwarjo, Konseling Teman Sebaya (Peer Counseling) untuk Mengembangkan Resiliensi Remaja, Makalah pada Seminar Pengembangan Ilmu Pendidiakn Fakultas Ilmu Pendidikan Universitas Negri Yogyakarta: 2008.

Sunarto, Perkembangan Peserta Dididk, Jakarta: PT Rineka Cipta, 1999.

Zakiah Daradjat, Pendidikan Islam dalam Keluarga dan Sekolah, Jakarta: Ruhama, 1993. 